\title{
Conceptions and Practices of Assessment in Higher Education: A Study of Portuguese University Teachers
}

\author{
Concepciones y Prácticas de Evaluación en la Educación \\ Superior: Un Estudio con Profesores Universitarios \\ Portugueses
}

\author{
Diana Ribeiro Pereira* y Maria Assunção Flores \\ Universidade do Minho
}

\begin{abstract}
This paper looks at how Portuguese university teachers look at assessment in Higher Education. It focuses on their conceptions and methods of assessment. Data were collected through face to face interviews and online open-ended questionnaires in five Portuguese Public Universities in different fields of knowledge. In total, 57 teachers participated in this study. Findings are presented according to the emerging categories arising from the data analysis: i) university teachers' conceptions of assessment; ii) most used assessment methods; iii) role of assessment; iv) key moments in which assessment is put into practice. Implications of the findings are discussed.
\end{abstract}

Keywords: Assessment, Higher Education, Teaching, Learning, Assessment methods, Conceptions of assessment.

Este artículo analiza cómo los profesores universitarios portugueses ven la evaluación en la Educación Superior. Se centra en sus concepciones y métodos de evaluación. Los datos fueron recolectados mediante entrevistas cara a cara y cuestionarios online de composición abierta en cinco Universidades Públicas Portuguesas en diferentes campos del conocimiento. En total, 57 profesores participaron en este estudio. Los resultados se presentan según las categorías emergentes que surgen del análisis de los datos: i) las concepciones de la evaluación de los profesores universitarios; ii) el papel de la evaluación; iii) los momentos clave en que se utiliza la evaluación; iv) los métodos de evaluación más usados. Se discuten las implicaciones de los datos.

Palabras clave: Evaluación, Educación Superior, Enseñanza, Aprendizaje, Métodos de evaluación, Concepciones de evaluación.

*Contacto: dianapereira@ie.uminho.pt issn: 1989-0397

www.rinace.net/riee/ https://revistas.uam.es/riee
Recibido: $\quad 15$ de julio de 2015

$1^{\text {a }}$ Evaluación: 27 de septiembre de 2015

$2^{\text {a }}$ Evaluación: 15 de noviembre de 2015

Aceptado: $\quad 2$ de diciembre de 2015 


\section{Introduction ${ }^{1}$}

Assessment in higher education impacts on students' learning in various ways (Ramsden, 2004; Gibbs, 1999; Scouller, 1998; Simms \& George, 2014). The ways in which assessment is carried out have implications for students' learning (Segers, Gijbels, \& Thurlings, 2008) and impact on them even before they are assessed (Rowntree, 1987), namely in terms of their approaches to learning (Boud \& Falchikov, 2006; Fletcher, Meyer, Anderson, Johnston, \& Rees, 2012). The ways in which teachers see assessment influence their assessment practices and how they relate these practices to the teaching and learning process (Fletcher et al., 2012; Samuelowicz \& Bain, 2002). Teachers' approaches to teaching are also related to their conceptions of teaching (Trigwell \& Prosser, 1996) which will influence in turn how they assess students' learning (Watkins, Dahlin, \& Ekholm, 2005). Earlier studies show how different conceptions of teaching and learning impact on students' assessment. Prosser and Trigwell (1998) identify two conceptions of teaching and learning: 1) teachers who look at learning as joining of information view teaching as transmission of information to students and are more focused on themselves as teachers; and 2) teachers who see learning as transforming the students' conceptions view teaching as helping, developing and changing these conceptions and thus are more student-focused. Samuelowicz and Bain (2002, p. 181) found that "different teachers' orientations result in different assessment practices". Teachers who see the teaching and learning process as reproduction or transmission of knowledge view assessment as students' ability to reproduce the knowledge acquired. In contrast, teachers who see teaching as facilitating learning and promoting critical thinking view assessment as transformation of knowledge and as an integral part of the learning process (Samuelowicz \& Bain, 2002).

This assumption is in line with existing literature. Ramsden (2004), for instance, reports that teachers who see teaching as knowledge transmission see assessment as a separate element of teaching instead of an integrated approach that promotes deep approaches to learning. Postareff and Lindblom-Ylänne (2008) found that teachers who see teaching as construction of knowledge tend to adopt several and different assessment practices rather than just the traditional ones. This may be related to another study of Postareff, Virtanen, Katajavuori and Lindblom-Ylänne (2012) which indicates that the majority of teachers use summative assessment and traditional methods and a minority uses formative assessment and a range of different methods.

These different perspectives show how conceptions of teaching and learning may influence teachers' attitudes towards assessment. In fact, teachers' conceptions of assessment may influence their teaching practices (Brown, 2004; Brown, Lake, \& Matters, 2011; Pajares, 1992) and students' learning (Brown \& Hirschfeld, 2008; Marton \& Saljo, 1997).

Remesal (2011) proposed a model about the conceptions of assessment regarding four different dimensions: 1) learning process; 2) teaching process; 3) accreditation of

\footnotetext{
1 This work was supported by the Portuguese Foundation for Science and Technology under
} the Grant SFRH/BD/76175/2011. 
learning and 4) accountability of the professional teaching activity. In this paper, the term conceptions of assessment is used in relation to teachers' views about assessment concerning the dimension of the learning process, the teaching process and the accreditation of learning since they are aligned with the focus of this study.

Although there are studies focusing on teachers' and students' conceptions of assessment and their impact on learning (Brown \& Hirschfeld, 2008; Fletcher et al., 2012; Gibbs \& Simpson, 2004) more needs to be known about teachers' beliefs related to assessment and their assessment practices, as well as the relationship between their beliefs and the processes of teaching, learning and assessment (Samuelowicz \& Bain, 2002). Accordingly, it is important to get to know the ways in which university teachers' look at assessment, because their conceptions of teaching, learning and assessment influence how they teach and how students learn (Brown, 2004; Thompson, 1992).

This study intends to illustrate the conceptions of Portuguese university teachers on the assessment process after the so-called Bologna process. The reorganisation of higher education systems in Europe has challenged the ways of looking at curricula but also to teaching, learning and assessment (Flores \& Veiga Simão, 2007; Flores, Veiga Simão, Barros, \& Pereira, 2015; Simão, Santos, \& Costa, 2003). Among the key features of the Bologna Process is the emphasis on a student-centred approach involving new forms of teaching and learning with tutorial support (Leuven / Louvain-la-Neuve Communiqué, 2009) and the use of innovative methods that promote participatory learning and the development of critical thinking (Bucharest Communiqué, 2012). However, these changes may not occur in all higher education systems in the same way. Therefore, as the context of this study is part of the European Area of Higher Education (EAHE), implemented by the Bologna Process, this study may contribute to get to know the university teachers' perceptions of assessment as to compare and contrast them with findings obtained in other contexts.

\section{Conceptions of Assessment}

Assessment has been investigated in all levels of teaching. It has developed according to different understandings and conceptions such as assessment as a tool for learning (Dochy \& McDowell, 1997) as improvement for teaching and learning (Brown et al., 2011) and learner-centred assessment (Webber, 2012) moving beyond the perspective of accreditation and certification. These conceptions focused on the potential benefits that assessment can bring to the learning process (Dochy \& McDoweel, 1997) in its formative nature (Brown et al., 2011) and in the use of assessment methods that look at student as learner (Webber, 2012). The assessment functions may also determine the learning process. Hadji (1994) suggests that assessment has three main functions, corresponding to three main different goals: the purpose of certification associated with summative assessment; the purpose of regulation associated with formative assessment and the purpose of guidance associated with diagnostic or prognostic assessment. The certification, often seen as the traditional function of the assessment, assures the potential employer that a given student obtained the required training by recognising his/her competencies. However, this provides vague details of the kinds of knowledge and skills acquired by the student and the level of mastery in each one. It only informs about what the student knows in general and if the student reached the goals to pass or to start a profession (Perrenoud, 1999). In addition, this kind of assessment develops 
hierarchies of excellence, establishing the progression of a cycle of studies and students are usually compared among themselves (Boud, 2000; Fletcher et al., 2012; Hadji, 1994) by obtaining a grade (Perrenoud, 1999). Thus, summative assessment entails a sum of a course, performed at a given time, being an assessment that measures results achieved by the students (Light \& Cox, 2003). Some authors suggest that summative assessment is opposed to formative assessment (Bloom, Hastings, \& Madaus, 1971; Light \& Cox, 2003) since the goal is to make a very general assessment of the degree in which objectives have been achieved during the course or for any substantial part of it, usually taking place at the end of a period of the year to assign a note and subsequently a certificate (Brew, Riley, \& Walta, 2009). In contrast, formative assessment has a pedagogical propose and it is intrinsic to the process of teaching itself (Brown \& Knight, 1994; Hadji, 1994). The formative role of assessment is important to improve learning, because it provides students with feedback during the process of learning (Brown, Bull, \& Pendlebury, 1997). It also enables them to have opportunities to improve (Brown, Race, \& Rust, 2004) making it possible for both students and teachers to get to know how learning is proceeding (Biggs, 2003) essentially its successes and difficulties.

Biggs (2003) makes a clear distinction between the general purposes of these two types of assessment: formative and summative. The author suggests that summative assessment is labelled often as a negative assessment, since it creates surface approaches to learning and the students use less their cognitive skills (less than currently required), which results in a fragmented learning. In regard to formative assessment, the feedback that results from it facilitates learning, promotes the necessary information for deep approaches to learning resulting in a further development of cognitive activities that are appropriate to the level of the proposed task. However, Black and William (1998) found that formative assessment also entails some weaknesses when it is put into practice in contexts in which there is lack of awareness among teachers about the formative purpose of assessment. The authors also found that teachers value most the grading function than the learning function (Black \& William, 1998).

\section{Assessment Methods in Higher Education}

The assessment methods adopted by university teachers have an important role in the quality of learning (Atkins, 2004; Fernandes, Flores, \& Lima, 2012; Flores et al., 2015; Hue, Leung, \& Kennedy, 2014; MacLellan, 2004; Pereira, Flores, \& Niklasson, 2015). Several factors are influential of the most used assessment methods, either negatively or positively, especially on student learning and may be seen as an incentive for study and for improved performance (Biggs, 2003; Boud \& Falchikov, 2007; Brown \& Knight, 1994; Brown et al., 1997; Watering, Gijbels, \& Dochy, 2008). The ways in which students look at learning are influenced by the ways in which they perceive assessment tasks (Brown \& Knight, 1994; Drew, 2001).

Also, teaching methods must be aligned with assessment methods, taking into account the learning goals in order for teaching to be more effective (Biggs, 2003). While teachers see the objectives of the curriculum as key elements in the teaching and learning process, students look mainly at the ways in which assessment is carried out (Biggs, 2003; Ramsden, 2004). For this reason assessment cannot be seen as the end of the process (Dochy \& McDowell, 1997) in so far as students pay attention at it at first 
and then based on that they create a defined representation of the curriculum and activities in which they are to be involved (Meyers \& Nulty, 2009). The use of given assessment methods and their adequacy to teaching and learning goals are thus of paramount importance. However, traditional methods frequently used in higher education, such as the exam or written test, while they are effective in some contexts and for given purposes, may not be suitable for all assessment purposes and may encourage reproduction and memorisation (Biggs, 2003; Pereira \& Flores, 2012; Perrenoud, 1999). In fact, existing research shows that written tests promote low levels of comprehension (Dochy, Segers, Gijbels, \& Struyven, 2007), reproduction of information under pressure and surface approaches to learning (Brown et al., 1997). On the other hand, the so-called alternative assessment methods or learner-centred methods (Webber, 2012), such as portfolios, projects, self- and peer assessment, simulations, collaborative assessment, among others (Struyven et al., 2005; Flores et al., 2015; Pereira et al., 2015) promote collaborative learning, and together with self and peer assessment seem to be more effective regarding deep learning and the development of new skills and professional attitudes. These methods also enable a more effective learning (Birenbaum \& Feldman, 1998; Sambell \& McDowell, 1998; Struyven, Dochy, \& Janssens, 2005; Tang, Lai, Arthur, \& Leung, 1999), fostering the development of autonomy, sense of responsibility, and reflection (Sambell \& McDoweel, 1998) and influencing the ways in which students see their own learning in a more positive way (Sluijsmans, Dochy, \& Moerkerke, 1998). These methods also provide students with feedback about their performance (Brown et al., 1997) and prepare them to workplace situations (Biggs, 2003). Other studies, however, suggest that the non-traditional methods do not always change the perceptions of students nor lead to deep learning (Segers et al., 2008). As such, the different approaches to learning may be influenced by the assessment methods and assessment tasks used (Struyven et al., 2005; Fletcher et al., 2012) but also by the contexts in which they are used. Often, the problem of students having a surface approach to learning has to do with assessment tasks which relate to teachers' practices and the alignment with the aims of teaching and its environment (Biggs, 2003). Thus it is important to investigate the conceptions of assessment and the practices used by university teachers in different fields of knowledge.

\section{Methods}

This paper draws upon a wider piece of research within the context of a $\mathrm{PhD}$ in Educational Sciences, with a grant from the Portuguese Foundation for Science and Technology (SFRH/BD/76175/2011). The following questions are addressed in this paper:

1. How do university teachers look at assessment in Higher Education (HE)?

2. What kinds of assessment methods are used in HE? And why?

3. How do university teachers relate assessment methods and issues of teaching and learning?

\subsection{Participants}

The participants in this study are university teachers teaching year 3 in five Portuguese Public Universities. In total 57 teachers participated in the study (see table 1); $53 \%$ are male and $47 \%$ are female teachers. Their age ranged between 30 and 68 
years old. Most of them (58\%) are Assistant Professors and the years of teaching experience in HE ranged between 2 and 44 years. Most of them have 29 years of teaching. Out of 57 teachers 32 teach in Social Sciences and Humanities, 10 in Life and Health Sciences, 9 in Natural and Environmental Sciences and 6 in Sciences and Engineering.

Out of the 57 teachers 24 were face-to-face interviewed and 33 teachers responded to the questions using the link provided via email. In this study the four scientific fields of research identified at the Portuguese Foundation for Science and Technology were used: Social Sciences and Humanities (SSH), Life and Health Sciences (LHS), Natural and Environmental Sciences (NES) and Sciences and Engineering (ESE). Different programmes were selected: SSH: (Educational Sciences, Basic Education and Economics); LHS: (Nursing, Medicine, Pharmacy); NES: (Biology, Geology) and SE: (Mechanical Engineering, Computers Engineering and Biochemistry) which were operating in the five public universities.

Table 1. Participants

\begin{tabular}{llr}
\hline \multicolumn{1}{c}{ FIELD OF KNOWLEDGE } & & F \\
\hline \multirow{3}{*}{ Social Sciences and Humanities } & Educational Sciences & 17 \\
& Economics & 12 \\
& Basic Education & 3 \\
& Total & 32 \\
\hline \multirow{2}{*}{ Life and Health Sciences } & Nursing & 5 \\
& Medicine & 4 \\
& Pharmacy & 1 \\
& Total & 10 \\
\hline \multirow{2}{*}{ Natural and Environmental Sciences } & Biology & 9 \\
& Total & 9 \\
\hline \multirow{3}{*}{ Sciences and Engineering } & Mechanical Engineering & 4 \\
& Computer Engineering & 1 \\
& Biochemistry & 1 \\
& Total & 6 \\
\hline
\end{tabular}

Source: Prepared by the authors.

\subsection{Data collection and analysis}

Data were collected between October 2012 and June 2013 in five Portuguese Public Universities. A research protocol was sent to the Presidents of Faculties and Institutes and to the Presidents of the Pedagogical Council of each Faculty and Institute in order to request permission to conduct the study. After obtaining the authorisation to conduct the study directors of the different programmes were contacted in order to obtain the email contacts of the teachers who were teaching in the third year of each programme. The interview protocol was validated with teachers teaching in one Public university between March and May 2012.

Face to face interviews and responses via email were received from 10 out of the 14 programmes selected. The participants were identified within the different departments in each programme. They were invited to participate in a face-to-face interview. Some of them were very busy and preferred to participate by sending their responses via email. For that a link with open-ended questions were created which was sent to them via email. Informed consent and confidentiality were granted for both the interviews and responses sent via email. The interview protocol was designed to obtain 
data on the conceptions of assessment, assessment methods used in $\mathrm{HE}$ and connections between assessment, teaching and learning (see appendix 1).

This study is based on the interpretative paradigm which focuses on the interpretation of a phenomenon by understanding the meanings through the experiences of the individuals in a constantly changing reality (Blaikie, 2010; Cohen, Manion, \& Morrison, 2008). Within this framework, through the use of qualitative methods the researcher has a systematic and integrated idea of the context and the holistic dimension in order to obtain a complex and substantial information (Miles, Huberman, \& Saldaña, 2014). Therefore, a qualitative research design was adopted as it allowed exploring university teachers' views enabling a deeper understanding of the phenomenon (Silverman, 2013) and its complexity (Miles \& Huberman, 1994). The interview was chosen because it enabled a broad retrospective, a projection of the actions, feelings, experiences of individuals and knowledge (Kvale, 1996). Interviews were transcribed verbatim. Content analysis was used to identify emerging categories, enabling a systematic description, through the categorisation of data (Schreier, 2012). Content analysis as a technique to analyse data performs valid inferences, leading to the emergence of what is relevant (Weber, 1990) and answer to research questions (Thomas, 2003).

\section{Findings}

Findings are presented according to the emerging categories arising from the data analysis: i) university teachers' conceptions of assessment; ii) most used assessment methods; iii) role of assessment; iv) key moments in which assessment is used.

\subsection{University teachers' conceptions of assessment}

The following section describes the findings regarding the conceptions of assessment in terms of better assessment for students to learn. Teachers spoke of continuous assessment during the process, formative assessment, and assessment based on active and participatory methods as the kinds of assessment that may help students learn better. Other participants do not point to any kind of assessment method as being better; some of them state that university teachers should use different methods to assess depending on the course or module.

Most of the participants claim that continuous assessment helps the students to learn better "together with independent work of the student with individual feedback" (P.4 $\mathrm{SSH})$.

Some of them argue that this kind of assessment brings benefits to learning, namely if it is based "on a continuous logic that promotes a better quality of learning" (P.24 $\mathrm{SSH})$. Also, continuous assessment is said to "promote critical thinking" (P.49 LHS).

Some university teachers believe that combining continuous assessment with formative assessment is positive for students' learning: “A continuous assessment, more personalised and adapted to each case, more formative and with possibility of reconstruction of knowledge is better" (P.25 SSH).

However, some of them point to difficulties in putting continuous assessment in practice in universities due to the number of students and heavy workload: "The ideal is a continuous assessment but it is impossible (P.37 NES) and "Continuous assessment 
is the ideal, but there is a problem, it is hard to do continuous assessment in a class with 90 students" (P.45 LHS).

Formative assessment is seen, by some teachers, as important to students' learning: "The formative assessment is the best assessment form. With formative assessment the students have to face situations, have to share and are always being monitored" (P.56 $\mathrm{SSH})$.

However, like continuous assessment, formative assessment is difficult to be put into practice:

I have no doubts that formative assessment is the best assessment for students' learning. The entire reproductive model evokes in the student an intellectual detachment, because the students do not participate and are not motivated, so the traditional model is not good... the formative assessment model needs more teachers, more resources, more technology and our country does not have fund for it. (P.47 SSH)

Assessment based on practical and active methods are seen as important for learning and improvement: "Assessment has to be combined with goals and methodologies of work, and the more effective is the use of active methods (P.22 SSH).

The importance of the practical context in assessment is also highlighted.

It is important to promote long-term learning and reasoning. Students will be future doctors and will be faced with questions on a daily basis, they will have to think and reflect, and if we use an assessment methodology that only point to memorisation they will not be prepared. The best assessment method will be the one that is based on practical things and prepare them for the practical context. (P.46 LHS)

Teachers emphasise continuous assessment and formative assessment as the best assessment to help students to learn better because it allows feedback and the reconstruction and regulation of learning. Assessment based on active and participatory methods is also pointed out by the participants. However, a number of constraints hinder the use of these assessments due to the number of students or to the number of teachers or to reasons related to available resources as can be seen in the following teacher account:

I have introduced before new active methods such as PBL. However, I think that Bologna is not an effective process, because not everybody shares the principles of Bologna, not everyone discusses these changes. I do not see how Bologna can work in classes with 100 students (...) governments that signed this document are not consistent (...) we face reductions in all resources. Education should be individualised because each student is different, and in our public universities this does not exist, we are talking about mass education. (P.43 CVS)

It is also claimed that there is a lack of conditions to put into practice some of the demands of the Bologna Process, as a student centred-approach, continuous assessment and the skills' development through assessment practices. Furthermore, the Bologna Process "has followed different paces, across and within countries, and that the coexistence of the old and new systems in some countries has most likely favoured the emergence of controversy regarding its implementation in higher education institutions, students and labour markets" (Portela, Sá, Alexandre, \& Cardoso, 2009, p. 466). These factors may explain, at least in part, some resistance to follow the assumptions of the Bologna Process, particularly with regard to the teaching, learning and assessment process, appearing not exist a common and shared view of the teaching and assessment practices across the European countries. 


\subsection{Most used assessment methods}

Findings indicate that 41 out of the 57 teachers interviewed used written tests (see table 2). Practical work in groups, oral presentations, individual work and reports are also identified by some university teachers. Other assessment methods, although less used, included written reflections, interviews, literature review, reading tasks, etc.

Table 2. Assessment methods most used by the participants

\begin{tabular}{lccccc}
\hline & N & SSH (N=32) & LHS (N=10) & NES (N=9) & ESE (N=6) \\
\hline Tests/Exam & 41 & 18 & 10 & 8 & 5 \\
Practical work in group & 18 & 12 & 2 & 3 & 1 \\
Oral Presentations & 15 & 6 & 2 & 4 & 3 \\
Individual work & 10 & 6 & 2 & 2 & 0 \\
Report & 8 & 3 & 2 & 1 & 2 \\
\hline
\end{tabular}

Source: Prepared by the authors.

As observed in table 2, written test or exam is one of the most recurring methods. These finding corroborates earlier studies that show that traditional assessment methods are the most used in higher education (Struyven et al., 2005; Flores et al., 2015; MacLellan, 2001). Although the test is the method most used, it is used differently depending on the field knowledge. In LHS all teachers used tests. In NES 8 out of 9 respondents used test such as in the case of ESE, in which 5 out of 6 teachers report using written tests. Regarding SSH teachers, 18 out of 32 interviewed teachers mentioned written tests as the most used assessment method. Furthermore, findings show that LHS, NES and ESE used more the test as the preferred method of assessment than their SSH counterparts (only over half of the teachers use it). However, other methods more focused on learner and skills' development are used by teachers as it is the case of practical work in groups that allows collaborative work or oral presentations that encourage students to develop communication skills.

Regarding the effectiveness of assessment methods, the participants state that the written test is the more effective assessment method. Other methods are also considered to be as effective methods such as group or individual work, methods based on continuous assessment, project-based work and oral presentations.

The participants point out that written tests require students' effort and they are more efficient than other assessment methods: "Exams require students to make an individual effort and that can be later seen as beneficial in their professional lives" (P.27 $\mathrm{SSH}$ ); "Exams force students to make the information more systematic and they reflect they effort individually" (P.19 SSH).

However, others are critical of using written tests because they promote memorisation rather than understanding: "If you value memorisation, you choose the summative test, but students study and spend some time and after that they no longer know anything" (P.52 SSH), "I don't use tests and exams because for me they are episodes of memorisation" (P.34 SSH), "Methods that foster the memorisation rather than understanding such as tests do not enhance student learning" (P.46 LHS).

On the other hand, teachers claim that the assessment methods used on the basis of a continuous assessment are more effective.

Continuous assessment through inquiry-based work and project-based work foster a process of more continuous study, more discussion between students and teachers and amongst students and promote the development of soft skills. (P.13 ESE) 
Formative feedback and systematic monitoring of learning are also the focus of continuous assessment in the participants' perspective.

The methods that enable continuous assessment are better. They enable the monitoring of individual work and self and peer assessment. Students can become more aware of their learning, overcome shortcomings, receive guidance, and be stimulated in order to feel more comfortable and safe in their own development and progression. (P.16 SSH)

Group work, oral presentations and projects are also pointed out by the participants. Group work is more effective because it promotes the development of communication skills, collaboration and it improves learning.

Group work is better because it implies more interaction between students and the teacher. It also leads to greater learning experience, not just memorisation and reproduction of knowledge. (P.54 SSH)

Oral presentations and projects are also identified as methods that promote research and self-monitoring of learning.

Projects and oral presentations of scientific papers are better methods to assess student learning. These methods provide students with opportunities to search for information and to self-regulate their learning. (P.26 ESE)

Although tests and exams were identified by teachers as the most effective methods to assess student learning, for some of them this method only promotes memorisation and it is used as a method for assessing large classes (Biggs, 2003; Pereira \& Flores, 2012). Students' perceptions regarding traditional assessment methods are also negative because they think they are inadequate and superficial as a tool to measure learning (Struyven et al., 2005). However, it is recognised that traditional methods may be suitable for certain purposes and in given contexts of teaching and learning (Flores et al., 2015). On the other hand, there is evidence that methods such as group work, oral assessment and practical works have benefits for learning and are significant for students' professional life (MacLallen, 2004; Taylor, 1997). Group work is a good example, since it allows the development of communication skills, group management, dealing with problems (Almond, 2009; Johnston \& Miles, 2004), and encourages students' motivation (Weurlander, Soderberg, Scheja, Hult, \& Wernerson, 2012). However, Flores et al. (2015) study show that when students are assessed by the socalled learner-centred methods the idea of conflict is more associated with assessment than when other (more traditional) assessment methods are used.

\subsection{Role of Assessment}

Findings from this study suggest that the participants use summative and formative assessment, although summative assessment is more used. In teachers' accounts both positive and negative aspects in formative and summative assessment are identified.

Summative assessment is used by most of them because it is an institutional requirement of all Portuguese universities participating in this study: "I use summative assessment at the end of the semester because the assessment standards of the university require so" (P.4 SSH); "The final summative assessment is compulsory at my institution" (P.26 ESE).

Some teachers agree to use summative assessment since it is efficient and effective and can act in the end as "a safeguard for the teacher" (P.52 SSH).

However, most teachers look at summative assessment as an unfair process due to its mandatory and reductionist nature. 
I use summative assessment because I have to. At the end of the day there is to be a mark and in this university all students are measured by a final grade, it is unfair. Sometimes students get 14.4 (out of 20) and will not have 15 and a student with 14.5 gets 15 at the end. (P.43 LHS)

Also, the difficulty of having to translate the entire assessment into a summative grade is reported by the participants: "I use summative assessment because I am forced to translate everything into a grade, because the university selects people" (P.47 SSH); "I use summative assessment and in the end the excel programme is in charge, but it is not a fair assessment" (P.39 LHS).

Formative assessment presents multiple benefits to the learning process. The monitoring of learning and the knowledge construction are positive aspects reported by the participants.

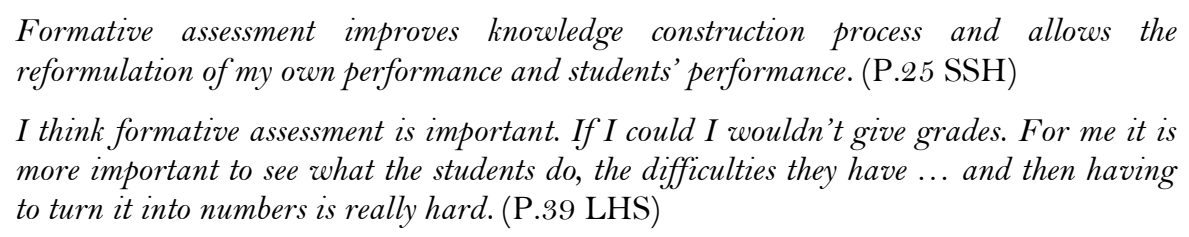

Feedback is also a key feature which continually regulates the learning process, and it is recognised by the participants as a tool to improve the learning process: "The cornerstone and the basic assumption is formative assessment. The grades come after that and result from continuous feedback" (P.40 SSH). Also:

I use formative assessment. In every classroom we discussed what they learned and students have contact with what they are learning. We do exercises and I only ask the students what I am capable of assessing, so they feel that all I ask is useful. I think that feedback is crucial, so all I ask I have to have time to look and analyse. (P. 50 SSH)

The participants also highlight that formative assessment enables students to develop competencies and to improve their performance.

I see many advantages in formative assessment, because we cannot see the process as a product; there is also the development of skills and feedback to the students to improve their learning. It is important for them in order to change their behaviours. And there is only learning when there is change of a particular behaviour. (P.49 LHS)

In addition to improve students' performance, teachers hold the idea that formative assessment also allows the regulation of teaching and learning process: "I always use formative assessment. The idea is that the student in the end meets the goals and this requires reformulating the teaching and learning process" (P.24 SSH).

Other benefits were also associated with formative assessment such as encouragement of the critical thinking:

Formative assessment helps students to understand how they produced the materials, what kinds of mistakes they made and they may incorporate formative feedback in their next work, improving their own working style, intellectual study, learning, improving the methods for learning and developing their skills. For example, when it is noted that a student is more reproductive he/she is encouraged to take a more analytical and critical stance. (P. $41 \mathrm{SSH})$

The fairness of formative assessment is also presented in the participants' accounts:

Formative assessment is fairer and better for the student. Because if the student only performs a test he/she can be in a bad day and something happens and will affect all the work that he/she developed until then. (P. 46 LHS) 
There was also evidence of formative assessment as the assessment that is more suitable to higher education purposes.

Formative assessment is the most important. It corresponds to my idea of university and the role of the teacher and his/her work. It corresponds to my idea of ethics and responsibility to the student. It is a way of seeing education (P.47 SSH) or I use formative assessment because it is the assessment that best responds to the modernisation of higher education. (P.26 ESE)

Although formative assessment is said to have benefits for learning, some participants state that it is not feasible in higher education due to the number of students, lack of resources and available time: "We are unable to use formative assessment and formative assessment is important. In a lecture hall with 100 students it is unthinkable" (P.45 LHS); "In undergraduate education the formative assessment does not make sense, it only makes sense at the master degree level” (P.35 SSH). Also:

I cannot use formative assessment because I have no time and it forces me to do something that I'm not good at, I mean to distribute the interactivity with the students and it is difficult. (P.37 NES)

These findings are in line with Gibbs and Simpson (2004) who identified constraints that reduce the use of formative assessment in higher education: short courses, consequently less contact hours, increase in the number of examinations and issues related to staff. These constraints inhibit the quality and quantity of feedback given and influence the use of assessment practices.

Finally, some participants did not answer if they use or not formative and summative assessment because they did not know what it meant. Findings reveal that they pointed out more positive aspects related to formative assessment rather than to summative assessment (see figure 1). In the participants' opinion, the positive aspects of formative assessment are related to the teaching and learning process. These positive aspects reveal a concern with the learning process regarding knowledge, monitoring of learning, skills' development and feedback. Positive aspects are associated with teachers' conceptions on assessment: fairness and the idea of university. With regard to summative assessment, the positive aspects related to the rationality of effectiveness and efficacy of assessment process and as a proof that they can serve as justification if the teacher needs one. The constraints of formative assessment are related to lack of time, large number of the students, heavy workload whereas the constraints of summative assessment are associated with an institutional obligation and its unfairness nature. In general, formative assessment is related to the improvement of learning and requires certain conditions to be implemented in an effective manner. Summative assessment is associated with systematisation of assessment concerning efficacy and effectiveness, and as a teacher's safeguard as well as an institutional requirement.

Other studies corroborate these findings and show that assessment in higher education serves different purposes (Boud, 1995). MacLellan (2001) found that summative assessment is seen by both teachers and students as the purpose of assessment and synonymous with give and receive marks. The fact of assessment is seen as the purpose of assessment may be related to the summative assessment in some contexts as an institutional requirement. On the other hand, the study by Samuelowicz and Bain (2002) concerning teachers' orientations to assessment practice shows that teachers view the purpose of assessment as support to the students' learning and feedback. 


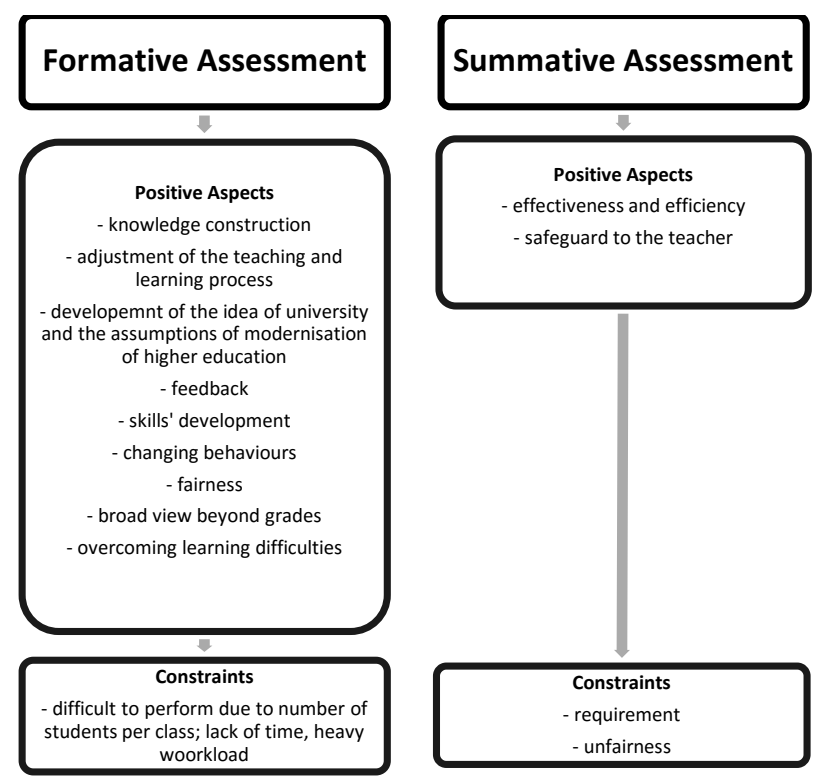

Fig 1. Positive aspects and constraints of summative and formative assessment Source: Prepared by the authors.

\subsection{Key moments in which assessment is used}

Teachers assess students' learning in three different moments: (1) during the process of teaching and learning and at the end of the course; 2) during the process of teaching; and 3) every time students perform a task.

Most of the teachers assess students' learning during the process of teaching and learning and at the end of the course: "I assess during the semester, after the delivery of students' work. At the end of the semester after students' perform an exam" (P.13 ESE); "I assess during the semester and at the end. However, I assess during the semester only when there is sufficient topics to be reviewed" (P.27 SSH); "There are always several moments of assessment during the semester and final examinations must be offered to the students according to the university Regulation" (P.26 ESE).

The phase of assessing during the process is especially related to continuous assessment: "As I use continuous assessment, it is being done throughout the semester and at the end there is a more formal self and peer assessment" (P.25 SSH); "I use formative assessment during the semester and summative assessment at the end with group work" (P.22 SSH).

Other participants state that the assessment is carried out only during the semester and again the idea of a continuous assessment is highlighted. The participants claim that continuous assessment brings benefits for students and it is more effective:

\footnotetext{
It makes sense to develop continuous assessment throughout the semester, it fosters students' motivation to come to classes and it is effective and continuous. If they are missing they are not admitted to the exam. (P.42 ESE)

I use continuous assessment. It is the commitment between having a perspective of what will happen and the feasibility of what is possible because to assess all classes is impossible. (P.55 SSH)
}

However, the participants also explain that there are certain rules that do not allow them to perform the assessment only during the process: "I assess my students throughout the Curricular Unit. Then there are formal moments due to the constraints 
that we have" (P. 43 LHS); "The Pedagogical Council determines the periods of written assessments (test/exam). The remaining assessments occur during the semester" (P.8 $\mathrm{SSH})$.

Some accounts also reveal that the participants assess students' learning every time a student performs a task: "I always try to provide students with feedback when they perform a task, an activity. Because I believe that this is the most effective way to assess" (P.16 SSH); "I assess in all classes, whenever they do a task" (P.29 SSH).

From other university teachers' accounts assessment is also carried out only at the end of the course: "As we have few weeks of classes I only assess at the end of the assessment elements" (P.45LHS), "I assess only at the end of the year" (P.30 SSH).

Also a periodic assessment is reported by the participants: "The assessment of attitudes is continuous and the assessment of knowledge acquired is done in given moments" ( $\mathrm{P}$. 48 LHS).

Some participants explain that they assess all the time: "I assess all the time to maintain self-learning and self-regulation" (P.4 SSH); "I assess throughout the semester, but especially over the last month, when the students have assimilated much of the content" (P.2 SSH).

Other university teachers, however, claim that it: "depends on the nature of the Curricular Unit” (P. 1 ESE).

In the participants' accounts it is clear the idea of the importance of continuous assessment throughout the process with benefits for the learning process. However, when most teachers assess during the semester, they normally use tests and they associate them with university requirements. A number of constrains were also identified in their accounts, namely the imposition of assessment. The idea of assessing only throughout the process of teaching and learning allows them a given effectiveness in assessment as it requires students to attend classes. Other participants claim that they assess every time a student performs a task emphasising the importance of timely and continuous feedback. On the other hand, none of participants mentioned that assessing at the beginning of the semester or at the beginning of a module. The participants seem to use formative assessment in their practices, however, they do not assess at the beginning of a module or coursework. One might question if they actually use formative assessment and how they use it and what kind of feedback they provide and when as although teachers say they use formative assessment, their practices go against it (MacLellan, 2001).

\section{Discussion}

This paper sets out to analyse the conceptions of assessment and assessment methods used in higher education from teachers' point of view. Data highlight that assessment that can help students to learn better is continuous assessment. The participants view formative assessment as important, although most of them use summative assessment because it is compulsory in higher education institutions. In their perspective, formative assessment improves the learning process, allows the monitoring of learning and feedback, identifies learning difficulties and it is a fairer assessment mode. However, together with continuous assessment, formative assessment is seen as not feasible to implement in higher education due to the number of students per class, lack of resources, heavy workload and lack of time. Given these constraints, teachers resist 
to use certain forms of assessment such as continuous, formative assessment and the use of participatory methods. On the other hand, summative assessment is seen by university teachers as more efficient and effective, as it can work as a proof of student performance within the institution. However, summative assessment is also regarded by them as compulsory and unfair. Although some participants claim that they use formative assessment, one might question its purpose and effect taken into account the moments of assessment and the nature of the methods that are used.

The participants look at assessment as a continuous process throughout teaching and learning as it brings benefits such as learning monitoring through feedback and students' attendance to classes. Although they state that continuous assessment is important, they also recognise that there must be final formal assessment methods, which are determined by the university, in some cases, and normally it is a written test at the end of the semester, which they see as a formal constraint.

Thus the participants hold different conceptions of assessment and one might question how continuous and formative assessment is understood. The participants tend to associate more continuous assessment with written tests throughout the semester and less with formative and timely feedback to students.

Some participants see assessment as summative emphasising its effective dimension and reporting its mandatory nature. Other teachers see assessment as formative as synonymous with development, learning, knowledge, adjustment and improvement. The divergence of perspectives is associated with the lack of clear institutional policy on assessment practices and previous experiences of the university teachers (Fletcher et al., 2012; McMillan, 2003). As a result, research is needed about how conceptions of assessment can be influenced and enhanced the institutional policy (Rust, 2007; Brown, 2004).

The written test is the most used assessment method. Practical work in groups, oral presentations, individual work and reports are also used too but their use is less frequent. Teachers recognise the importance of assessment methods that allow continuous assessment, guidance, monitoring of learning and skills' development. Some of them also recognise that traditional methods promote memorisation rather than knowledge. Although they recognise the importance of student-centred assessment methods, written tests continue to be the most used method identified by the participants. As Ramsden (2004) states, there is not a method that satisfies all educational goals, therefore diversity and a balance in assessment methods are key issues in order to innovate and improve assessment practices.

\section{Conclusion}

In conclusion, this study provides evidence that there is a contradiction between the assessment practices that the participants claim to be most beneficial to students' learning and those they claim to use in practice. This contradiction between their conceptions of assessment and the practices they claim to use may be explained by different reasons: heavy workload, lack of human and physical resources in higher education contexts and the obligation of using summative assessment imposed by universities which inhibits the use of practices centred on the learner perpetuating, thus, the use of traditional assessment methods. The results of this study will contribute to understand how assessment process is carried out in some contexts within the Portuguese higher education. 
This study suggests recommendations for further research. It would be important to understand if the university teachers' conceptions of assessment have direct influence on their assessment practices. It would also be important to understand why teachers' conceptions of assessment are different from those that are put in practice by them as well as the perceptions of their students. Also, further research is needed on university teachers' conceptions of assessment and their relation with students' achievement (Brown \& Hirschfeld, 2008).

\section{References}

Almond, R. (2009). Group assessment: Comparing group and individual undergraduate module marks. Assessment \& Evaluation in Higher Education, 34(2), 141-148. doi:10.1080/02602930801956083.

Atkins, M. (2004). What should we be assessing? In P. Knight (Ed.), Assessment for learning in higher education (pp. 25-33). Birmingham: SEDA.

Biggs, J. (2003). Teaching for quality learning at university. Buckingham: SHRE \& Open University Press.

Birenbaum, M., \& Feldman, R. (1998). Relationships between learning patterns and attitudes towards two assessment formats. Educational Research, 40(1), 90-98. doi: 10.1080/0013188980400109.

Black, P., \& Wiliam, D. (1998). Inside the Black Box: Raising standards through classroom assessment. London: School of Education, King's College.

Blaikie, N. (2010). Designing social research. United Kingdom: Polity Press.

Bloom, B., Hastings, J., \& Madaus, G. (1971). Manual de avaliação formativa e somativa do aprendizado escolar. São Paulo: Pioneira.

Boud, D. (1995). Assessment and Learning: contradictory or complementary? In P. Knight (ed.), Assessment for learning in higher education (pp. 35-48). London: Kogan Page Limited.

Boud, D. (2000) Sustainable assessment: Rethinking assessment for the learning society. Studies in Continuing Education, 22(2), 151-167. doi:10.1080/713695728.

Boud, D., \& Falchikov, N. (2006). Aligning assessment with long-term learning. Assessment Eீ Evaluation in Higher Education, 31(4), 399-413. doi:10.1080/02602930600679050

Boud, D., \& Falchikov, N. (2007). Rethinking assessment in higher education: Learning for the long term. New York: Routledge.

Brew, C., Riley, P., \& Walta, C. (2009). Education students and their teachers: Comparing views on participative assessment practices. Assessment and Evaluation in Higher Education, 34(6), 641-657. doi:10.1080/02602930802468567.

Brown, G. (2004). Teachers' conceptions of assessment: Implications for policy and professional development. Assessment in Education: Principles, Policy E Practice, 11(3), 301-318. doi:10.1080/0969594042000304609

Brown, G., Bull, J., \& Pendlebury, M. (1997). Assessing student learning in higher education. London: Routledge.

Brown, G., \& Hirschfeld, G. (2008). Students' conceptions of assessment: Links to outcomes. Assessment in Education: Principles, Policy \& Practice, 15(1), 3-17. doi:10.1080/09695940701876003.

Brown, S., \& Knight, P. (1994). Assessing learners in higher education. London: Kogan Page. 
Brown, G., Lake, R., \& Matters, G. (2011). Queensland teachers' conceptions of assessment: The impact of policy priorities on teacher attitudes. Teaching and Teacher Education, 27(1), 210-220. doi:10.1016/j.tate.2010.08.003.

Brown, S., Race, P., \& Rust, C. (2004). Using and experiencing assessment. In P. Knight (Ed.), Assessment for learning in higher education (pp. 75-85). Birmingham: SEDA.

Bucharest Communiqué. (2012). Making the most of our potential: Consolidating the European Higher Education Area.

Cohen, L., Manion, L., \& Morrison, K. (2008). Research methods in education. London: Routledge.

Dochy, F., \& McDowell, L. (1997). Assessment as a tool for learning. Studies in Educational Evaluation, 23(4), 279-298. doi:10.1016/So191-491X(97)86211-6.

Dochy, F., Segers, M., Gijbels, D., \& Struyven, K. (2007). Assessment engineering: Breaking down barriers between teaching, and learning and assessment. In D. Boud \& $\mathrm{N}$. Falchikov (Eds.), Rethinking assessment in higher education: Learning for the longer term (pp. 87-100). New York: Routledge.

Drew, S. (2001). Student perceptions of what helps them learn and develop. Teaching in Higher Education, 6(3), 309-331. doi:10.1080/13562510120061197.

Fernandes, S., Flores, M., \& Lima, R. (2012). Students' views of assessment in project-led engineering education: Findings from a case study in Portugal. Assessment E Evaluation in Higher Education, 37(2), 163-178. doi:10.1080/02602938.2010.515015.

Fletcher, R., Meyer, L., Anderson, H., Johnston, P., \& Rees, M. (2012). Faculty and students conceptions of sssessment in higher education. Higher Education, 64(1), 119- 133. doi:10.1007/s 10734-011-9484-1.

Flores, M., \& Veiga Simão, A. M. (2007). Competências desenvolvidas no contexto do Ensino Superior: A perspectiva dos diplomados. In M. Iglesias Martínez \& F. Pastor Verdú (Eds.), Actas das V Jornadas de Redes de Investigación en Docencia Universitaria. Alicante: Universidad de Alicante.

Flores, M., Veiga Simão, M., Barros, A., \& Pereira, D. (2015). Perceptions of effectiveness, fairness and feedback of assessment methods: A study in higher education. Studies in Higher Education, 4O(9), 1523-1534. doi:10.1080/03075079.2014.881348.

Gibbs, G. (1999). Using assessment strategically to change the way students learn. In S. Brown \& A. Glasner (Eds.), Assessment matters in higher education: Choosing and using diverse approaches (pp. 41-53). Buckingham: SHRE \& Open University Press.

Gibbs, G., \& Simpson, C. (2004). Conditions under which assessment supports students' learning. Learning and Teaching in Higher Education, 1, 3-31. Retrieved from http://www.open.ac.uk/fast/pdfs/Gibbs\%20and\%20Simpson\%202004-05.pdf

Hadji, C. (1994). A Avaliação, regras do jogo: Das intenções aos instrumentos. Porto: Porto Editora.

Hue, M., Leung, C., \& Kennedy, K. (2014). Student perception of assessment practices: Towards 'no loser' classrooms for all students in the ethnic minority schools in Hong Kong. Educational Assessment Evaluation and Accountability, 27(3), 253-273. doi:10.1007/s1 1092014-9205-2.

Johnston, L., \& Miles, L. (2004). Assessing contributions to group assignments. Assessment \& Evaluation in Higher Education, 29(6), 751-768. doi:10.1080/0260293042000227272.

Kvale, S. (1996). Interviews: An introduction to qualitative research interviewing. London: SAGE Publications.

Leuven/Louvain-la-Neuve Communiqué. (2009). Communiqué of the Conference of European Ministers Responsible for Higher Education. 
Light, G., \& Cox, R. (2003). Learning and teaching in higher education: The reflective professional. London: Sage Publications.

MacLellan, E. (2001). Assessment for learning: The differing perceptions of tutors and students. Assessment $\oint^{2}$ Evaluation in Higher Education, 26(4), $307-318$. doi:10.1080/02602930120063466.

MacLellan, E. (2004). Authenticity in assessment tasks: A heuristic exploration of academics' perceptions. Higher Education Research and Development, 23(1), 19-33. doi:10.1080/0729436032000168478.

Marton, F., \& Saljo, R. (1997). Approaches to learning. In F.Marton, D. Hounsell, \& N. Entwistle (Eds.), The experience of learning. Implications for teaching and studying in higher education (pp. 39-58). Edinburgh: Scottish Academic Press.

McMillan, J. H. (2003). Understanding and improving teachers' classroom assessment decision making: Implications for theory and practice. Educational Measurement: Issues and Practice, 22(4), 34-43. doi:10.1111/j.1745-3992.2003.tbo0142.x.

Meyers, N., \& Nulty, D. (2009). How to use (five) curriculum design principles to align authentic learning environments, assessment, students' approaches to thinking and learning outcomes. Assessment \& Evaluation in Higher Education, 34(5), 565-577. doi:10.1111/j.1745-3992.2003.tbo0142.x.

Miles, M., \& Huberman, M. (1994). Qualitative data analysis (2nd ed.). Thousand Oaks, CA: Sage Publications.

Miles, M., Huberman, M., \& Saldaña, J. (2014). Qualitative data analyisis. A methods sourcebook. Thousand Oaks, CA: Sage Publications.

Pajares, F. (1992). Teachers' beliefs and educational research: Cleaning up a messy construct. Review of Educational Research, 62(3), 307-332. doi:10.3102/00346543062003307.

Pereira, D., Flores, M., \& Niklasson, L. (2015). Assessment revisited: A review of research in Assessment and Evaluation in Higher Education. Assessment $\mathcal{E}^{\circ}$ Evaluation in Higher Education. doi:10.1080/02602938.2015.1055233.

Pereira, D., \& Flores, M. (2012). Percepções dos estudantes universitários sobre a avaliação das aprendizagens: Um estudo exploratório. Avaliação (Campinas), 17(2), 529-56. doi:10.1590/S1414-40772012000200012.

Perrenoud, P. (1999). Avaliação, Da excelência à regulação das aprendizagens: Entre duas lógicas. Porto Alegre: ARTMED.

Portela, M., Sá, C., Alexandre, F., \& Cardoso, A. (2009). Percepetions of the Bologna Process: What do students' choices reveal? Higher Education, 58(4), 465-474. doi:10.1007/s 10734009-9205-1.

Postareff, L., \& Lindblom-Ylänne, S. (2008). Variation in teachers' descriptions of teaching: Broadening the understanding of teaching in higher education. Learning and Instruction, 18(2), 109-120. doi:10.1016/j.learninstruc.2007.01.008.

Postareff, L., Virtanen, V., Katajavuori, N., \& Lindblom-Ylänne, S. (2012). Academics' conceptions of assessment and their assessment practices. Studies in Educational Evaluation, 38(3-4), 84-92. doi:10.1016/j.stueduc.2012.06.003.

Prosser, M., \& Trigwell, K. (1998). Understanding leaning and teaching: The experience in higher education. Buckingham: SHRE \& Open University Press.

Ramsden, P. (2004). Learning to teach in higher education. London: Routledge Falmer. 
Remesal, A. (2011). Primary and secondary teachers' conceptions of assessment: A qualitative study. Teaching and Teacher Education, 27(2), 472-482. doi:10.1016/j.tate.2010.09.017.

Rowntree, D. (1987). Assessing students: How shall we know them? London: Kogan Page.

Rust, C. (2007). Towards a scholarship of assessment. Assessment E Evaluation in Higher Education, 32(2), 229-237. doi:10.1080/02602930600805192.

Sambell, K., \& McDowell, L. (1998). The values of self and peer assessment to the developing lifelong learner. In C. Rust (Ed.), Improving student learning: Improving students as learners (pp.56-66). Oxford: Oxford Center for Staff and Learning Development.

Samuelowicz, K., \& Bain, J. D. (2002) Identifying academics' orientations to assessment practice. Higher Education, 43(2), 173-201. doi:10.1023/A:1013796916022.

Schreier, M. (2012). Qualitative content analysis in practice. London: SAGE Publications.

Scouller, K. (1998). The influence of assessment method on students' learning approaches: Multiple choice question examinations versus assignment essay. Higher Education, 35(4), 453-472. doi:10.1023/A:1003196224280.

Segers, M., Gijbels, D., \& Thurlings, M. (2008). The relationship between students' perceptions of portfolio assessment practice and their approaches to learning. Educational Studies, 34(1), 35 -44. doi:10.1080/03055690701785269.

Silverman, D. (2013). Doing qualitative research: A practical handbook. London: SAGE Publications.

Simão, J. V., Santos, S., \& Costa, A. (2003). Ensino Superior: Uma visão para a próxima década. Lisbon: Gradiva.

Simms, M., \& George, B. (2014). Approaching assessment from a learning perspective: Elevating assessment beyond technique. Educational Assessment Evaluation and Accountability, 26(1), 95- 104. doi:10.1007/s1 1092-013-9176-8.

Sluijsmans, D., Dochy, F., \& Moerkerke, G. (1998). Creating a learning environment by using self, peer and co-assessment. Learning Environment Research, 1(3), 293-319. doi:10.1023/A:1009932704458.

Struyven, K., Dochy, F., \& Janssens, S. (2005). Students' perceptions about evaluation and assessment in higher education: A review. Assessment $\mathcal{E}^{2}$ Evaluation in Higher Education, 30(4), 331-347. doi:10.1080/02602930500099102.

Tang, C., Lai, P., Arthur, D., \& Leung, S. (1999). How do students prepare for traditional and portfolio assessment in a problem-based learning curriculum? In J Conway \& A. Williams (Eds.), Themes and Variations in PBL: Refereed proceedings of the 1999 Bi-ennial PBL Conference Vol.1 (pp. 206-217). Sydney: Australia Problem-Based Learning Network (PROBLARC).

Taylor, I. (1997). Developing learning in professional education. Buckingham: SHRE \& The Open University Press.

Thomas, R. (2003). Blending qualitative and quantitative research methods in theses and dissertations. Thousand Oaks, CA: Sage Publications.

Thompson, A. G. (1992). Teachers' beliefs and conceptions: A synthesis of the research. In D. Grouws (Ed.), Handbook of research on mathematics teaching and learning (pp. 127-146). New York: Macmillan.

Trigwell, K., \& Prosser, M. (1996). Changing approaches to teaching: A relational perspective. Studies in Higher Education, 21(3), 275-284. doi:10.1080/03075079612331381211. 
Watering, G., Gijbels, D., Dochy, F., \& Rijt, J. (2008). Students' assessment preferences, perceptions of assessment and their relationships to study results. Higher Education, 56(6), 645-658. doi:10.1007/s10734-008-9116-6.

Watkins, D., Dahlin, B., \& Ekholm, M. (2005). Awareness of the backwash effect of assessment: A phenomenographic study of the views of Hong Kong and Swedish lecturers. Instructional Science, 33(4), 283-309. doi:10.1007/s11251-005-3002-8.

Weber, R. (1990). Basic content analysis. Newbury Park, CA: Sage Publications.

Webber, K. (2012). The use of learner-centered assessment in US colleges and universities. Research in Higher Education, 53(2), 201-228. doi:10.1007/s11162-011-9245-0.

Weurlander, M., Soderberg, M., Scheja, M., Hult, H., \& Wernerson, A. (2012). Exploring formative assessment as a tool for learning: Students' experiences of different methods of formative assessment. Assessment \& Evaluation in Higher Education, 37(6), 747-760. doi:10.1080/02602938.2011.572153. 


\section{Appendix 1. Interview schedule (example)}

Questions related to conceptions of assessment

In your opinion, taking into account your experience, what kind of assessment can help students learn better?

Do you use formative assessment? Why?

And summative assessment? Why and when?

In general, when you assess the students' learning? At the beginning of the semester, during the semester, at the end of the semester, or whenever the student performs a task? Why?

Questions related to assessment methods

What are the assessment methods you use the most?

Taking into account your experience as a teacher, what are the most effective methods of assessment in terms of teaching and learning? Why? 